\title{
Identifying the main factors involved in business intelligence implementation in SMEs
}

\author{
Juan Alexis Becerra-Godínez, José Leonardo Serralde-Coloapa, Martin Salvador Ulloa-Márquez, \\ Abraham Gordillo-Mejía, Elizabeth Acosta-Gonzaga \\ Instituto Politécnico Nacional-Unidad Profesional Interdisciplinaria de Ingeniería y Ciencias Sociales y \\ Administrativas, Mexico
}

\begin{tabular}{|c|c|}
\hline Article Info & ABSTRACT \\
\hline Article history: & \multirow{9}{*}{$\begin{array}{l}\text { In recent years, the use of information and communication technology (ICT) } \\
\text { tools has been recognized as a critical element for the development } \\
\text { of enterprises; being mainly exploited by large companies. However, small } \\
\text { and medium enterprises (SMEs) have yet opportunities to take advantage } \\
\text { of them; this is the case of the implementation and usage of business } \\
\text { intelligence (BI), which is a term that encompasses applications, tools, } \\
\text { and methodologies that support decision-making process at a managerial } \\
\text { level. Nevertheless, so far there is not a clear approach for its adoption } \\
\text { in SMEs, for this reason, this work aims to identify the main factors involved } \\
\text { in Business Intelligence implementation in SMEs through a literature review. } \\
\text { Information for the analysis was gathered from scientific databases. } \\
\text { The results showed main factors that influence the adoption of BI } \\
\text { technologies in SMEs as well as recommendations given by several authors } \\
\text { to ensure success in the process. }\end{array}$} \\
\hline Received Jan 21, 2019 & \\
\hline & \\
\hline Acce & \\
\hline Keywords: & \\
\hline Business intelligence; & \\
\hline Business intelligence adoption; & \\
\hline Docume & \\
\hline terprises & \\
\hline
\end{tabular}

This is an open access article under the $\underline{C C B Y-S A}$ license.

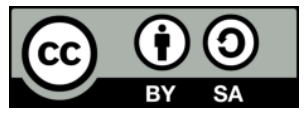

\section{Corresponding Author:}

Elizabeth Acosta-Gonzaga, Instituto Politécnico Nacional, Unidad Profesional Interdisciplinaria de Ingeniería y Ciencias Sociales y Administrativas, Av. Té 950, Granjas México, 08400 Ciudad de México, CDMX, Mexico.

Email: eacostag@ipn.mx

\section{INTRODUCTION}

In recent years, it has been recognized that information and communications technology (ICT) is essencial for the development of society, these have led to changes in the way we work to access more competitive markets [1,2]. ICT is also a key element for the performance of companies' processes, which are measured by productivity, efficiency, and profitability. Currently, obtaining technological infrastructure does not guara ntee that a company can obtain competitive advantages, the knowled ge owned by an organization is actually recognized as the only competitive force in the current world [3], contrasting with the condition of Mexican SME's, where a lack of quality information, standardized processes, and information flows, which means a disadvantage in the market [4]. Likewise, SMEs has limited resources which affect the participation of IT projects [5].

Among current existent technology, information systems are highlighted, which are defined as the set of components that interrelate the processes of information management for decision making [6], having a raw material data that, by itself, is meaningless, but is subsequently stored, processed and transformed to obtain meaningful information. At the end of the process, feedback is required in order to know if the information is useful for a current situation, as shown in Figure 1 [7]. The data are considered a critical piece that helps to improve decision making in an organization, which allows an enterprise 
to be a participant in a digital age [8]. Masclef, Juárez, \& Bazzano [9] mentioned five types of information systems according to the business organization levels, starting at an operational level, the creators of knowledge, followed by an administrative level, or middle management, and strategic level (management), as shown in Table 1.

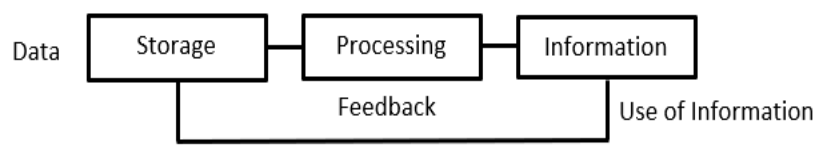

Figure 1. Information system in the organization [7]

Table 1. Types of information systems

\begin{tabular}{|c|c|}
\hline Types of system & Functionality \\
\hline Transaction Processing System (TPS) & $\begin{array}{l}\text { Systems that support the registration of transactional information, giving service at an } \\
\text { operational level in the functional areas of sales, marketing, manufacturing, production, } \\
\text { finance, accounting, human resources, among others. }\end{array}$ \\
\hline Knowledge Work System (KWS) & $\begin{array}{l}\text { Information systems designed to create knowledge, among which are the word processors, } \\
\text { email messages and presentations. }\end{array}$ \\
\hline Management Information System (MIS) & $\begin{array}{l}\text { They provide support at the administrative level for planning and control processes, in such } \\
\text { a way that generate regular reports in a summarized manner. }\end{array}$ \\
\hline Decision Support System(DSS) & $\begin{array}{l}\text { Support at the administrative level in an organization, nevertheless, in contrast with MIS, } \\
\text { DSS perform a combination of generated data within an organization, and it is s upp or ted } \\
\text { by analytical models and tools thathelp to visualize it according to the company's objective } \\
\text { and its construction of the system. }\end{array}$ \\
\hline Executive Support System(ESS) & $\begin{array}{l}\text { It provides support at a strategic level based on both internal and external data, ex tracting } \\
\text { information from internal MIS and DSS. They are displayed in graphs and general reports. }\end{array}$ \\
\hline
\end{tabular}

During the last decades, information systems have become more relevant to companies. For example, a decision support system which is an interactive system that helps to solve user problems and give the right result when a decision is difficult to make [10]. An essential part of DSS is the Business Intelligence (BI henceforth), which dates back to the early 50s' when the term was coined by Peter Luhn, a German computer scientist, who, through his article entitled "A Business Intelligence System" [11] defined it based on the following concepts:

- Business: a set of activities of commerce, technology, industry, law, government.

- Communication: a facilitator to understand a business.

- Intelligence: the ability to learn from facts presented, to guide actions towards the proposed objective.

- System: a source of information that supports specific activities in the organization.

In this way, he considered that BI is "a system that supports the acquisition, dissemination, storage, retrieval, and transmission of new information to perform functions more efficiently and take advantage of the support from new technologies" [11]. Business intelligence has the primary purpose of supporting the decision-making process, doing effective and innovative management [12]. However, it was not until the late '80s, when Howard Dresner of Gartner Group was recognized as the pioneer of BI, that the term was popularized and described as a general term that includes applications, tools and information analysis that helps performance and optimization of organizations' decisions [13]. Business intelligence can be called a support system which helps to obtain more accurate data analysis [14].

At first, it was believed that large companies were the only ones that were able to implement this type of technology, nevertheless, subsequently, and because of the importance of SMEs in the economic context, the implementation of BI in them has been the subject of study of multiple authors, such as Boonsiritomachai, McGrath \& Burgess [15], Mohammad, Mohammad \& Mohammad [16], Prieto, Meneses \& Venega [17] and Puklavec, Olivera \& Popovic [18], who focused on studying models to mea sure the level of maturity of technology adoption in SMEs; on the other hand, Casado \& Jímenez [19], Gauzelin \& Bentz [20], Lackman \& Lanasa [21], Pîrlog \& Ovidiu [22], Placer, Pérez, \& Soto [23], Seyyed, Shirkavand, Chalak, \& Rezaeei [24], Tarek \& Adel [25] and Wright, Bisson, \& Duffy [26] focused on the impact of BI implementation in SMEs in the industrial, hotel, and marketing sectors. Cho, Yoon, Coh, and Lee [27] identified the BI practices carried out by SMEs in the manufacturing sector in Korea; Larivet, Smith, \& Wright [28] and Smith, Wright, \& Pickton [29] also identified BI practices in the economic intelligence policies in France and BI practices in the Argentinian SMEs by Tovar[30] were studied.

Nyblom, Behrami, Nikkilä, \& Søilen [31] developed an evaluation model to measure the performance of BI in Swedish companies, while Legendre [32] performed a BI measurement model 
to know the level of BI that exists naturally within the companies. Galindo, Sanz, \& De-Benito [33] made a methodology proposal for the development of BI in SMEs. There are other studies which developed different models of BI for SMEs, such as Tarek \& Adel [25] that generated a BI model in North Africa SMEs and, TSONIŞ \& Bucea [34] who proposed a model for BI of SMEs in Romania. Other studies managed and processed data through BI, such as that of Augusto \& Pereira [35], who made a large-scale database on cancer studies, in the same way, Blanco, Milena, Córdoba, \& Ballesteros [36] managed the information obtained from social networks for its application in the Pedagogical and Technological University of Colombia.

There are other BI studies in SMEs, which were developed for different sectors, such as the study by Gutiérrez, Rodríguez, \& Castro [37], focused on proposing a model in the sales area of the SMEs' restaurant sector. Vanegas \& Guerra [38] developed a BI system in aqueduct and sewerage businesses. Sobrosa \& da Silva [39] proposed another modelfocused on the needs of the managers in a service company. Bajo, Borrajo, De Paz, Corchado, \& Pellicer [40] mentioned methods to prevent risks in internal audit through the use of BI; Lee, Lau, Ho, \& Ho [41] pointed out studies to coordinate supplies.

The related works with the closest approach to the critical points for BI adoption in SMEs are those that have elaborated a literature review, such as the work of Papachristodoulou, Koutsaki \& Kirkos [42], who contributed to understanding the problems and application of BI in SMEs. The results show the studies most related to BI: tools and solutions, implementation methods, as well as the benefits and challenges of BI in SMEs. However, in this study, the benefits and challenges are only theoretical supported by two studies. Likewise, Villamarín and Díaz [43] proposed a conceptual framework of the success factors in BI solutions within organizations, without including SMEs.

Qushem et al. [44] identified the factors involved in determining the efficiency of BI in SMEs; however, only explores Malaysian SMEs. Ali, Khan \& Miah [45], aimed to determine the effects and interactions of the relationship between BI and SMEs in the business context. Their results show that SMEs need to improve their capabilities (organizational and technological) for new BI innovations and to select the appropriate BI application to generate competitive advantages. Llave [46] conducted a literature review of the issues related to BI in SMEs, the results identified research topics such as BI components, BI solutions, BI adoption, implementation and benefits, cloud BI and, mobile BI; mentioning some knowledge gaps, such as determining the factors supporting the adoption and implementation of BI in SMEs.

Although previous studies have studied the issues related to BI in SMEs, only a few works mentioned factors and benefits [42-44, 46] influencing BI adoption in SMEs, although these issues are little addressed. For this reason, this research addresses the knowledge gap and provides the critical factors involved in implementing BI in SMEs context, and unlike the studies cited, it provides essential recommendations. This work contributes to identifying the essential factors that can help increase the odds of success in implementing BI projects in SMEs, providing knowledge mainly for SME managers or owners for their correct understanding and promotion. To do this, in the methods section, the parameters that were used to select the appropriate journals are described in a detailed manner, followed by the theoretical framework that details the analysis of the benefits, variables, and recommendations that influence the implementation of BI in SMEs, and finally, the conclusions are presented.

\section{RESEARCH METHOD}

Based on the processes mentioned in Figure 1, the keywords were selected: Business Intelligence, BI, Small and Medium Enterprises, SMEs and their combinations, in both English and Spanish. Next, specific databases were selected: Web of Science, Ebsco, and Redalyc. The type of documents analyzed is open access, those with restricted access or in a language other than Spanish or English were excluded. Then, it was corroborated that the documents obtained were at the context of BI in SMEs and subsequently, we selected the essential factors, 37 articles from different databases were analyzed, as shown in Table 2. The research was complemented by using several sources of information such as universities' collections and digital books.

Table 2. Information sources

\begin{tabular}{lc}
\hline \multicolumn{1}{c}{ Databases } & Number of articles \\
\hline Web of Science & 11 articles \\
Ebsco & 12 articles \\
Redalyc & 14 articles \\
Total & 37 articles \\
\hline
\end{tabular}




\section{RESULTS AND ANALYSIS}

After reviewing the articles and books, we identified several benefits of implementing BI in SMEs, variables that influence the implementation of BI in SMEs and recommendations that various researchers make for the implementation of BI in SMEs.

\subsection{Benefits of implementing BI in SMEs}

The use of BI is a cornerstone for strategic management in companies and can generate benefits, as shown in Table 3. Table 3 shows that the most relevant benefit was identified by Casado \& Jimenez [19]; Gauzelin \& Bentz [20], Hernández [7], Luhn [11], Vanegas \& Guerra [38], Papachristodoulou, Koutsaki \& Kirkos [42] and Canes in their studies, arguing that, if a BI project is implemented in a company, it supports the optimization of economic resources and time, and this propitiates an increase in margins of profit.

Table 3. Benefits of implementing BI

\begin{tabular}{lc}
\hline \multicolumn{1}{c}{ Benefits } & Reference \\
\hline Access to knowledge in real time & {$[35,47]$} \\
Foment of customer satisfaction & {$[35,46,48]$} \\
Improvementof knowledge management & {$[35,40,49]$} \\
Dissemination of best practices & {$[35]$} \\
Reduction of costs & {$[35,38]$} \\
Facilitation of work & {$[35,38,48,49]$} \\
Improve the diagnosis of data & {$[35,37,42,50]$} \\
Detection of risky situations & {$[16,23,33,40]$} \\
Provide a better internal understanding of the company & {$[40]$} \\
Optimization of economic and time resources to generatehigher profit margins & {$[19,20,33,38,42,51]$} \\
Facilitation the decision making of the company & {$[20,33,42,45,48]$} \\
Provide quality information, that is, errors-free and useful for interpreting the results & {$[20,39,42,48-50,52]$} \\
Improvement of productivity in the company & {$[20]$} \\
Promotion of a better performance of human resources & {$[20]$} \\
Provide dynamic and interactive reports for operators and managers & {$[38]$} \\
Provide detailed information & {$[38,48,49]$} \\
Provide an analy sis view & {$[38,49,50]$} \\
Allowance of viewing changes in the environment & {$[25]$} \\
Flexibility for information access & {$[42,46,49]$} \\
Generation of different views of the information needed by the management & {$[47]$} \\
Creation of stages based on evolution trends & {$[33]$} \\
Support of profitability of knowledge & {$[16]$} \\
\hline
\end{tabular}

The study of Tutunea \& Rus [50] has a more significant approach towards the benefits found by th is study. Nevertheless, they do not mention the prevention of risks, which is essential in helping to know the current situation of a company, reducing risk in predicting unexpected situations, generating knowledge for various scenarios that could cause such results, as well as, mitigating the impact of a loss, or knowing how to respond [40]. On the other hand, Hočevar \& Jaklič [48] evaluated the benefits that can be obtained from business intelligence through a study of case with a focus on SMEs, where it is mentioned that it is still difficult to measure the benefits of BI, since many people consider those intangible (non-quantifiable) assets, are usually the most important ones for a company. Meanwhile, Lueg \& Shijia [53] proved the usefulness of BI in SMEs through a case study with a budget approach. The findings show that the low quality of data is the main reason for incorrect budgeting process in the firm.

\subsection{Factors involved in the implementation of BI in SMEs}

Table 4 shows a set of factors that authors consulted in the literature review consider as crucial for the implementation of BI in SMEs; these can influence, both positively and negatively. Among the aspects mentioned in Table 4, Canes [51] suggests that the main factors influencing the adoption of BI in SMEs are the cost and complexity of BI system, this matches what mentioned Boonsiritomachai [15] who believes that the BI software systems integrate mathematical functions that make it difficult to use. However, the study of Mesquita [47] showed that after SME owners provided BI training to the staff, they learned to use the BI system more straightforward. Nyblom [31] mentions that hiring qualified personnel in B I knowledge would support the functioning of BI systems. Therefore, any changes associated with ICT lead to resistance to change, which is not entirely a constraint to achieve BI adoption in SMEs. 
Table 4. Factors that can influence the implementation of BI

\begin{tabular}{lc}
\hline & Factor \\
\hline The existence of a project leader & {$[47]$} \\
The time that takes implementing a BI project & {$[16,29,47]$} \\
There is a culture of information valorization & {$[16,35,47,52]$} \\
Age of the employees & {$[47]$} \\
The ease of use of the tool & {$[15,31,42,47,51]$} \\
The capability of the tool to provide quality information & {$[30,47]$} \\
The lack of knowledge of businesspeople about BI use & {$[26,30,39,47]$} \\
Skills of the employees of the IT area & {$[30]$} \\
Availability of BI tools providers & {$[15,30]$} \\
Ability to afford the costs generated when implementing BI tools & {$[15,20,26,29,30,32,51,52]$} \\
The existence of an organizational structure & {$[16]$} \\
Financial support & {$[16]$} \\
Cost of hiring a specialist forimplementing the project & {$[16]$} \\
Level of managers' compromise to support the introduction oftechnological innovations & {$[15,16,26]$} \\
Manager attitude towards BI project & {$[16]$}
\end{tabular}

On the other hand, the factor that has had the most significant impact in research of BI adoption in SMEs is the capability to pay the generated costs of implementing BI tools [20], the authors argue that usually, large companies are the ones who adopt BI technologies because they have enough resources to make it. On the other hand, the vast majority of SMEs have budget constraints $[26,51]$ to the acquisition of software, services, personnel, time, or are not willing to spend on BI tools [30]. Although most of the SMEs do not have sufficient resources for a sophisticated BI adoption, Merino [52] suggests asking for governmental support or try to adapt to alternatives for improvement, considering it as a BI project that involves costs, impacts, and sources. Therefore, as was mentioned in Boonsiritomachai [15], adopting any innovation would always be influenced by the availability of organizational resources.

\subsection{Recommendations for success in the adoption of BI in SMEs}

Table 5 shows some recommendations that authors considered as pertinent and required. These recommendations provide a guide for BI project implementation in order to make them successful. The results of Table 5 show that one of the recommendations that are most relevant during the implementation of BI in SMEs is to select the appropriate technology for the company depending on their needs. It will help to provide access to information more efficiently, and thereby contribute to collect, store and process data in a better way [31,38]. It is also essential to select the suitable system for the enterprise by analyzing the compatibility with other systems, the ability to learn, the support system, the users and the final price [31]. Nevertheless, as was mentioned in Papachristodoulo [42], the valid BI solution will always depend on the size of the SME, its organization and internalfactors.

Table 5. Recommendations for the success in the adoption of BI in SMEs

\begin{tabular}{lr}
\hline \multicolumn{1}{c}{ Recommendations } & Reference \\
\hline A general integrated methodology for planning a BI project & {$[24,33,39]$} \\
Decision-makers' requirements must beclear to make available theright information & {$[19,29]$} \\
Select the adequate technology for the company, suitable for its needs & {$[16,31,38,42]$} \\
Collection of information through internal surveys & {$[16]$} \\
Use the statistics for analyzing the information & {$[16]$} \\
Procure the minimization of resources of the leastimportant areas, so the budget is under control & {$[16]$} \\
Recruitment of qualified personnel & {$[16,31,51]$} \\
Look for advice from a BI specialist & {$[16]$} \\
Have the support of the administration to continue with the BI project & {$[18]$} \\
Link the vision of the BI project with the organization' objectives & {$[18]$} \\
Train the staff participating in the use of the BI tools onceimplemented & {$[18]$} \\
\hline
\end{tabular}

In order to ensure optimal results in implementing BI in SMEs, there must be an organizational structure and institutional policies that contribute to making the BI project; this should be supported by senior management of the company [16]. However, Canes [51] mention s that the lack of organizationalknowle dge is often an additional obstacle for SMEs, as they do not have trained entrepreneurs/managers to make strategic BI plans. Therefore, it is essential that SMEs find the qualified BI staff to provide a new vision of BI. 


\section{CONCLUSIONS}

This paper described the main critical points involved in the effective implementation of BI in SMEs, obtaining as results the benefits, recommendations, and factors involved in their implementation, which mainly refer to aspects of planning, business capacity, and organizational culture. The recommendations must be adapted according to the needs of each project systematically. The implementation of BI technologies in SMEs is an opportunity which has not been taken advantage of, mainly due to the lack of knowledge and strategic capacity of SMEs for generating technological innovations. Therefore, it can be concluded that there is still a long way to go for this technology to provide real support to the decision-making process. Future works may consider extending this review in a specific industrial sector.

\section{ACKNOWLEDGMENTS}

This work was supported by Instituto Politécnico Nacional(Grant 20194925).

\section{REFERENCES}

[1] Hoyos Chaverra J. A., Valencia Arias A., "El papel de las TIC en el entorno organizacional de las Pymes," Trilogía Cienc Tecnol Soc, vol. 4, no. 7, pp. 105-122, 2012.

[2] Cano G. Magister en Marketing, Magister en Docencia Universitaria e Investigación Educativa, Licenciado en Mercadotecnia, Ingeniero en Marketing y Finanzas, Ingeniero en Marketing y Finanzas, Docente de la San Gregorio de Portoviejo, Portoviejo, Ecuador, Rev Cient Dominio las Ciencias, vol. 4, pp. 499-510, 2018.

[3] Mohamed R, Mohd T, Abdul D, Noor A., "Antecedents of knowledge management practices: Case of malaysian practitioners," Bulletin of Electrical Engineering and Informatics (BEEI), vol. 7, no. 1, pp. 125-133, 2018.

[4] García Alcaraz D. A., Flores Verdugo G., "Las PyMES y la brecha digital: caso de Aguascalientes," En: Buenrostro Mercado E. Editor. Experiencias y desafíos en la apropiación de las TICs por las PyMEs Mexicanas. Primera edición. México: INFOTEC, pp. 45-55, 2013.

[5] El Yamami A., Mansouri K., Qbadou M., Illousamen E. H., "Multi-objective IT project selection model for improving SME strategy deployment," Int J Electr Comput Eng., vol. 8, no. 2, pp. 1102-1111, 2018.

[6] Laudon K., Laudon J., "Sistemas De Información Gerencial," Pearson Educación, pp. 15-27, 2012.

[7] Hernández A. Los Sistemas de Información: Evolución y Desarrollo. Dialnet, pp. 14, 1996, [Online], Available: from: https://dialnet.unirioja.es/descarga/articulo/793097.pdf

[8] Fang L. Y., Azmi N. F. M., Yahya Y., Sarkan H., Sjarif N. N. A., Chuprat S., "Mobile business intelligence acceptance model for organisational decision making," Bulletin of Electrical Engineering and Informatics (BEEI), vol 7, no. 4, pp. 650-656, 2018.

[9] Masclef M., Juárez E., Bazzano M., "Experiencias de empresas argentinas em implementaciones de sistemas de información," Rev Ciências da Adm, vol. 9, no. 18, pp. 169-182, 2007.

[10] Yesmaya V., Ronald A., Hidajat M., "Property Exhibition Decision Support System Based on Web Application," TELKOMNIKA (Telecommunication Comput Electron Control), vol. 16, no. 2, pp. 766-770, 2018.

[11] Luhn P. A., "Business Intelligence System," IBM J Res Dev, vol. 2, no. 4, pp. 314-319, 1958.

[12] Mishan M. T., Fadzil A. F. A., Samah K. A. F. A., Baharin N. F., Anuar N., "Business intelligence for paintball tournament matchmaking using particle swarm optimization," Indones J Electr Eng Comput Sci, vol. 11, no. 2, pp. 599-606, 2018.

[13] Gartner, "IT Glossary," 2018, [Online], Available: from: https://www.gartner.com/it-glossary/ business-intelligence-bi/

[14] Hayardisi G., Seminar K. B., Ramadhan A., "Analysing Signal Strength and Connection Speed in Cloud Networks for Enterprise Business Intelligence," TELKOMNIKA (Telecommunication Comput Electron Control), vol. 16, no. 4, pp. 1779-1784, 2018.

[15] Boonsiritomachai W., McGrath M., Burgess S., "Exploring business intelligence and its depth of maturity in Thai SMEs," Cogent Bus Manag, vol. 3, no. 1, pp. 1-17, 2016.

[16] Mohammad I., Mohammad R., Mohammad I., "Competitive Intelligence System in SMEs of Bangladesh: A Sense Making Approach," J Bus Econ., vol. 3, no. 2, pp. 180-213, 2011.

[17] Prieto R, Meneses C, Vega V., "Análisis comparativo de modelos de madurez en inteligencia de negocio," Ingeniare Rev Chil Ing, vol. 23, no. 3, pp. 361-371, 2015.

[18] Puklavec B., Oliveira T., Popovic A., "Understanding the determinants of business intelligence system adoption stages An empirical study of SMEs," Industrial Management and Data Systems, vol 118, no. 1, pp. 236-261, 2018.

[19] Casado G., Jímenez J., "Competitive Intelligence in the Tourism Sector, with special focus on Southern Europe Inteligencia Competitiva en el Sector Turístico, con especial atención al Sur de Europa," Tour Manag Stud, vol. 12, no. 1, pp. 136-144, 2016.

[20] Gauzelin S., Bentz H. H., "An examination of the impact of business intelligence systems on organizational decision making and performance: The case of France," J Intell Stud Bus, vol 7, no. 1, pp. 70-80, 2017.

[21] Lackman C., Lanasa J., "Competitive Intelligence and Forecasting Systems: Strategic Marketing Planning Tool for SME's," Atl Mark J, vol 2, no. 2, pp. 98-110, 2013. 
[22] Pîrlog R., Ovidiu A., "an Analyze Upon the Influence of the Key Performance Indicators (Kpi) on the Decision Process Within Small and Medium-Sized Enterprises (Sme)," Hyperion Int J Econophysics New Econ, vol. 9, no. 1, pp. 173-185, 2015.

[23] Placer-Maruri E., Pérez-González D., Soto-Acosta P., "Efectos de la utilización de la inteligencia competitiva en pymes industrials," Intang Cap, vol. 12, no. 4, pp. 923, Aug 2016.

[24] Seyyed Amiri N., Shirkavand S., Chalak M., Rezaeei N., "Competitive intelligence and developing sustainable competitive advantage," AD-minister, vol. 30, pp. 173-194, 2017.

[25] Tarek B., Adel G., "Business Intelligence versus Entrepreneurial Competitive Intelligence and International Competitiveness of North African SMEs," J Int Entrep, vol. 14, no. 4, pp. 539-561, 2016.

[26] Wright S., Bisson C., Duffy A., "Competitive Intelligence and Information Technology Adoption of SMEs in Turkey: Diagnosing Current Performance and Identifying Barriers," J Intell Stud Bus, vol. 2, pp. 5-29, 2013.

[27] Cho C., Yoon B., Coh B. Y., Lee S., "An empirical analysis on purposes, drivers and activities of technology opportunity discovery: The case of Korean SMEs in the manufacturing sector," $R$ D Manag, vol. 46, no. 1, pp. 13-35, 2016.

[28] Larivet S., Smith J., Wright S., "Developing a Typology of Competitive Intelligence Proficiency: The Case of French SMEs and Funded Intervention Programs," Manag Int. 2016;

[29] Smith J. R., Wright S., Pickton D., "Competitive Intelligence programmes for SMEs in France: evidence of changing attitudes," J Strateg Mark. vol. 18, no. 7, pp. 523-536, Dec 2010.

[30] Tovar C., "Investigación Sobre La Aplicación De Business Business Intelligence en la Gestión de las PyMEs de Argentina," Palermo Bus Rev, vol. 15, pp. 79-98, 2017.

[31] Nyblom M., Behrami J., Nikkilä T., Søilen K. S., "An evaluation of Business Intelligence Software systems in SMEs-a case study," J Intell Stud Bus, vol. 2, pp. 51-57, 2012.

[32] Legendre R., "Es la inteligencia de negocio aplicable a las PyMEs?," PUZZLE, vol. 17, pp. 4-9, 2005.

[33] Galindo J., Sanz P., De-Benito J., Necesidad de implantar una filosofía metodológica de Inteligencia Competitiva en PYMES y grupos de investigación basada en el análisis de patentes," Iber Conf Inf Syst Technol Cist, 2014, pp. 647-53.

[34] ŢONIŞ R., Bucea R., "Decision Support System Interface With Business Intelligence Solution for Romanian Small and Medium-Sized Enterprises," Ann Fac Eng Hunedoara, vol. 10, no. 3, pp. 29-34, 2012.

[35] Augusto A., Pereira J., "The Development of an ICT framework for Business intelligence at the Brazilian national Cancer Institute: a Case study of organizatinoal learning and Innovation," Rev Adm la Univ Fed St María, vol. 10, no. 3, pp. 551-566, 2017.

[36] Blanco T., Milena D., Córdoba A., "Ballesteros J. Gestión de datos obtenidos desde redes sociales aplicando Business Intelligence Engineering Process," Rev virtual Univ católica Norte, vol. 49, pp. 72-91, 2016.

[37] Gutiérrez J., Rodríguez L., Castro L., "Decision Support System for a SME in the Restaurant sector: Development of a Prototype," CISTI, vol. 60, pp. 2052-2057, 2007.

[38] Vanegas E., Guerra L. M. C., "Sistema de inteligencia de negocios para el apoyo al proceso de toma de decisions," Rev Ing UC, vol. 20, no. 3, pp. 25-34, 2013.

[39] Sobrosa F., da Silva S., Information architecture analysis using business intelligence tools based on the information needs of executives," J Inf Syst Technol Manag, vol. 10, no. 2, pp. 251-270, 2013.

[40] Bajo J., Borrajo M., De Paz J., Corchado J., Pellicer M. A., "multi-agent system for web-based risk management in small and medium business," Expert Syst Appl, vol. 39, no. 8, pp. 6921-6931, 2012.

[41] Lee C., Lau H., Ho G., Ho W., "Design and development of agent-based procurement system to enhance business intelligence," Expert Syst Appl, vol. 36, no. 1, pp. 877-884, 2009.

[42] Papachristodoulou E., Koutsaki M., Kirkos E. Business Intelligence and SMEs: Bridging the gap," J Intell Stud Bus," vol. 7, no. 1, pp. 70-80, 2017.

[43] Villamarín J., Díaz B., "Key success factors to business intelligence solution implementation," J Intell Stud Bus, vol 7, no. 1, pp. 48-69, 2017.

[44] Qushem U. Bin, Zeki A. M., Abubakar A., "Successful Business Intelligence System for SME: An Analytical Study in Malaysia," IOP Conf Ser Mater Sci Eng, vol. 226, pp. 1-9, 2017.

[45] Ali M. S., Khan S., Miah S. J., "Understanding towards Interactions between Business Intelligence and SMEs: Learn from Each Other," J Inf Syst Technol Manag, vol. 14, no. 2, pp. 158-168, 2017.

[46] Llave M. R., "Business Intelligence and Analytics in Small and Medium-sized Enterprises: A Systematic Literature Review," Procedia Comput Sci, vol 121, pp. 194-205, 2017.

[47] Fetzner M. A. de M., Freitas H., "Business Intelligence (BI) Implementation from the Perspective of Individual Change," JISTEM J Inf Syst Technol Manag, vol 8, no. 1, pp. 25-50, 2011.

[48] Hočevar B., Jaklič J., "Assessing Benefits of Business Intelligence Systems-a Case Study," Management, vol. 15, no. 1, pp. 87-119, 2010.

[49] Luciane R., Moreira A., "Un estudio de caso envolvendo Business Intelligence como instrumento de apoio á controladoria," Rev Contab Finanz. 2007;

[50] Tutunea M. F., Rus R. V., "Business Intelligence Solutions for SME’s," Procedia Econ Financ, vol. 3, no. 12, pp. 865-870, 2012

[51] Canes M. Business Intelligence for the SME. CA Mag. 2009; 46-48.

[52] Merino C., "Inteligencia Competitiva y PYMEs,"Puzzle, vol 4, no. 17, pp. 10-14, 2015.

[53] Lueg R, Shijia L., "How to improve efficiency in budgeting the case of business intelligence in SMEs," Eur J Manag, vol 13, no. 2, pp. 109-120, 2013. 